\title{
Metabolic engineering of Corynebacterium glutamicum for enhanced production of 5-aminovaleric acid
}

\author{
Jae Ho Shin ${ }^{1,2}$, Seok Hyun Park ${ }^{1,2}$, Young Hoon Oh' ${ }^{4}$, Jae Woong Choi ${ }^{1}$, Moon Hee Lee ${ }^{1,2}$, Jae Sung Cho ${ }^{1,2}$,
} Ki Jun Jeong ${ }^{1}$, Jeong Chan Joo ${ }^{4}$, James $\mathrm{Yu}^{2}$, Si Jae Park ${ }^{5^{*}}$ and Sang Yup Lee ${ }^{1,2,3^{*}}$ (D)

\begin{abstract}
Background: 5-Aminovaleric acid (5AVA) is an important five-carbon platform chemical that can be used for the synthesis of polymers and other chemicals of industrial interest. Enzymatic conversion of L-lysine to 5AVA has been achieved by employing lysine 2-monooxygenase encoded by the davB gene and 5-aminovaleramidase encoded by the davA gene. Additionally, a recombinant Escherichia coli strain expressing the davB and davA genes has been developed for bioconversion of L-lysine to 5AVA. To use glucose and xylose derived from lignocellulosic biomass as substrates, rather than L-lysine as a substrate, we previously examined direct fermentative production of 5 AVA from glucose by metabolically engineered $E$. coli strains. However, the yield and productivity of 5 AVA achieved by recombinant $E$. coli strains remain very low. Thus, Corynebacterium glutamicum, a highly efficient L-lysine producing microorganism, should be useful in the development of direct fermentative production of 5AVA using L-lysine as a precursor for 5 AVA. Here, we report the development of metabolically engineered C. glutamicum strains for enhanced fermentative production of 5AVA from glucose.
\end{abstract}

Results: Various expression vectors containing different promoters and origins of replication were examined for optimal expression of Pseudomonas putida davB and davA genes encoding lysine 2-monooxygenase and deltaaminovaleramidase, respectively. Among them, expression of the C. glutamicum codon-optimized davA gene fused with $\mathrm{His}_{6}$-Tag at its $\mathrm{N}$-Terminal and the davB gene as an operon under a strong synthetic $\mathrm{H}_{36}$ promoter (plasmid p36davAB3) in C. glutamicum enabled the most efficient production of 5AVA. Flask culture and fed-batch culture of this strain produced 6.9 and $19.7 \mathrm{~g} / \mathrm{L}$ (together with $11.9 \mathrm{~g} / \mathrm{L}$ glutaric acid as major byproduct) of 5AVA, respectively. Homology modeling suggested that endogenous gamma-aminobutyrate aminotransferase encoded by the gabT gene might be responsible for the conversion of 5 AVA to glutaric acid in recombinant $C$. glutamicum. Fed-batch culture of a C. glutamicum gabT mutant-harboring p36davAB3 produced $33.1 \mathrm{~g} / \mathrm{L}$ 5AVA with much reduced (2.0 g/L) production of glutaric acid.

Conclusions: Corynebacterium glutamicum was successfully engineered to produce 5AVA from glucose by optimizing the expression of two key enzymes, lysine 2-monooxygenase and delta-aminovaleramidase. In addition, production of glutaric acid, a major byproduct, was significantly reduced by employing C. glutamicum gabT mutant as a host

\footnotetext{
*Correspondence: parksj93@mju.ac.kr; leesy@kaist.ac.kr

${ }^{1}$ Department of Chemical and Biomolecular Engineering (BK21 Plus

program), Institute for the BioCentury, Center for Systems and Synthetic

Biotechnology, KAIST, 291 Daehak-ro, Yuseong-gu, Daejeon 34141,

Republic of Korea

${ }^{5}$ Department of Environmental Engineering and Energy, Myongji

University, 116 Myongji-ro, Cheoin-gu, Yongin, Gyeonggido 17058,

Republic of Korea

Full list of author information is available at the end of the article
} 
strain. The metabolically engineered C. glutamicum strains developed in this study should be useful for enhanced fermentative production of the novel C5 platform chemical 5AVA from renewable resources.

Keywords: 5-Aminovaleric acid, Corynebacterium glutamicum, L-Lysine, Metabolic engineering, Glutaric acid

\section{Background}

As a result of increasing pressure on the environment, bio-based production of chemicals, fuels, and materials from renewable non-food biomasses has been attracting much attention [1]. To make such bio-based processes competitive, microorganisms have been metabolically engineered for production of fuels [2-4], amino acids [59], polymers [10-12], and other chemicals of industrial importance [13-15]. It is expected that more chemicals and materials of petrochemical origin will be produced through bio-based route employing microorganisms developed by systems metabolic engineering $[16,17]$.

A non-proteinogenic $\omega$-amino acid, 5-aminovaleric acid (5AVA), has attracted attention as a five carbon (C5) platform chemical because of its potential in polymer synthesis [18-21]. 5AVA can be used to produce $\delta$-valerolactam (2-piperidone) via intramolecular dehydrative cyclization and can be further processed for synthesis of bio-based nylons, such as nylon- 5 and nylon-6,5 $[18,20]$. Enzymatic conversion of L-lysine to 5AVA has been achieved by employing lysine 2-monooxygenase (E.C. 1.13.12.2, encoded by the $\operatorname{dav} B$ gene) and 5-aminovaleramidase (E.C. 3.5.1.30, encoded by the $\operatorname{dav} A$ gene) [19]. We recently reported the development of a wholecell bioconversion process for conversion of L-lysine to 5AVA by employing recombinant Escherichia coli strains expressing lysine 2-monooxygenase and 5-aminovaleramidase as whole cell biocatalysts [20,21]. However, it is obviously desirable to use glucose derived from non-food lignocellulosic biomass as a substrate rather than L-lysine [1]. There have been reports on the development of metabolically engineered microorganisms for the production of $\mathrm{C} 3$ and $\mathrm{C} 4 \omega$-amino acids, such as $\beta$-alanine [22] and $\gamma$-aminobutyrate [23], from glucose. We and others also examined the possibility of producing the C5 $\omega$-amino acid 5AVA by metabolic engineering of $E$. coli, but the yield and productivity of 5AVA remain very low $[18,20]$. Thus, it is necessary to develop a new strategy for more efficient production of 5AVA.

Corynebacterium glutamicum is an organism widely used for the production of amino acids, proteins, monomers for plastic materials, and compounds for cosmetics [24, 25]. Additionally, C. glutamicum has been successfully engineered to produce a different C5-platform chemical, cadaverine (1,5-pentanediamine), and was shown to be a promising host for producing this chemical using different carbon sources, such as glucose and xylose [26-30]. Because C. glutamicum strains capable of producing L-lysine at very high levels have already been commercialized, we decided to exploit C. glutamicum as a host strain for the production of 5AVA.

In this study, we designed and introduced a synthetic pathway for the production of 5AVA into an L-lysineoverproducing C. glutamicum strain. The synthetic pathway consists of two key enzymes, lysine 2-monooxygenase encoded by the $\operatorname{dav} B$ gene and 5 -aminovaleramidase encoded by the $\operatorname{dav} A$ gene, responsible for the conversion of L-lysine to 5AVA. Various expression systems including vectors and promoters were examined for the most efficient production of 5AVA in C. glutamicum. A reaction responsible for unexpected formation of glutaric acid as a major byproduct was identified and subsequently deleted. The final engineered C. glutamicum strain was used for enhanced production of 5AVA by fermentation with much reduced glutaric acid.

\section{Results and discussion}

Construction of the 5AVA synthesis pathway in $C$. glutamicum by expressing the $\operatorname{dav} A B$ genes under the control of the tac promoter

Although 5AVA exists as an intermediate in amino acid degradation pathways in Pseudomonads, metabolic engineering for enhanced production of 5AVA requires strong metabolic flux from the chosen intermediate metabolite toward 5AVA as indicated by many successful examples of systems metabolic engineering $[16,17]$. Recombinant E. coli strains employing the $\operatorname{dav} A B$ genes from the L-lysine catabolic pathway of Pseudomonads were previously shown to produce 5AVA, although at low yield and productivity $[18,21]$. Because E. coli strains have a relatively low capacity to provide L-lysine as a precursor for 5AVA, high-level production of 5AVA could not be achieved in recombinant $E$. coli strains even though the L-lysine catabolic pathway via 5-aminovaleramide provides the shortest route from L-lysine to 5AVA $[18,21]$. Thus, C. glutamicum, the well-known, highly efficient L-lysine producing bacterium, was selected as a host strain for 5AVA production in this study to provide strong metabolic flux from glucose to L-lysine, the direct precursor of 5AVA $[5,6]$. This is strategically advantageous for producing compounds using L-lysine as a direct precursor.

To extend the metabolic flux from glucose toward 5AVA beyond L-lysine (Fig. 1a), P. putida ATCC 12633 


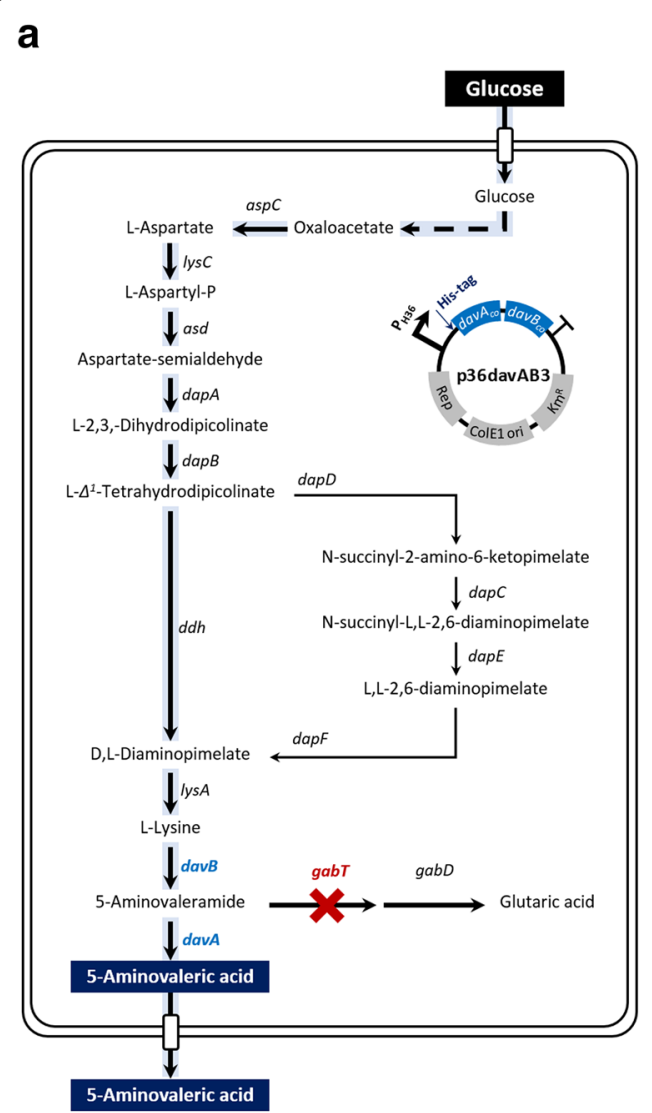

b

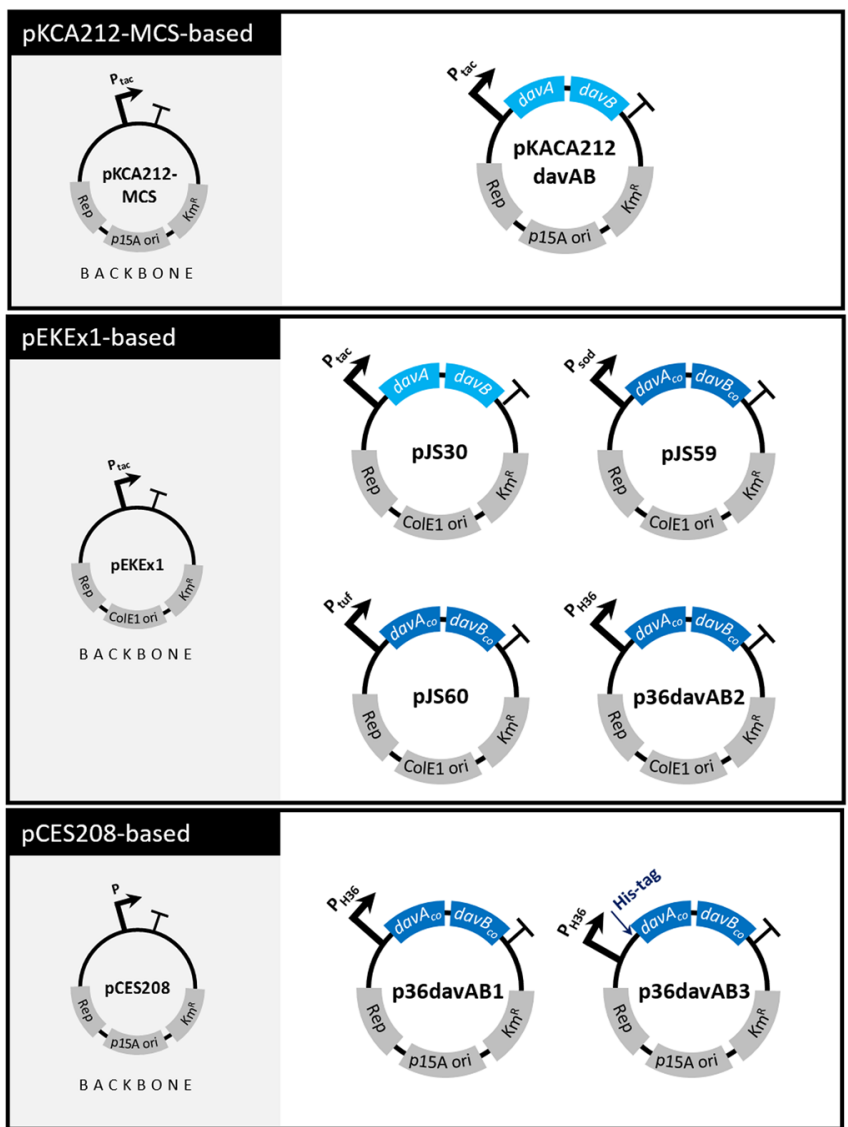

Fig. 1 Metabolic engineering strategies for 5AVA production using C. glutamicum. Heterologous expression of the P. putida davB gene (encoding L-lysine 2-monooxygenase) and the davA gene (encoding delta-aminovaleramidase) results in conversion of L-lysine into 5AVA. 5AVA5, 5-aminovalerate; ASP5 L-aspartate; ASP-P aspartyl phosphate; ASP-SA aspartate semialdehyde; LYS L-lysine

davAB genes $[20,21]$ were cloned in two different E. coliC. glutamicum shuttle vectors (Additional file 5: Table S1; Fig. 1b) and expressed in C. glutamicum BE strain (KCTC 12390BP). In plasmids pKCA212davAB and pJS30 (Fig. 1b), the $\operatorname{dav} A$ and $\operatorname{dav} B$ genes were organized in an operon and expressed under the control of the tac promoter, with an additional lacUV5 ribosome-binding site (tttcacacaggaaaca) for the $\operatorname{dav} B$ gene residing between the coding sequences of the two genes. Plasmid pKCA212davAB was constructed based on an in-house shuttle vector, pKCA212-MCS, whereas pJS30 was derived from pEKEx1 [31]. Plasmid pEKEx1 contains a pBL1 origin of replication, having $\sim 30$ copy numbers per cell in $C$. glutamicum [32], and pKCA212-MCS contains a pCC1 origin of replication, also having $\sim 30$ to $\sim 40$ copies per cell [33]. It was found that $C$. glutamicum BE could produce $17.2 \mathrm{~g} / \mathrm{L} \mathrm{L}$-lysine (yield of $325 \mathrm{mmol} / \mathrm{mol}$ glucose) in shake-flask cultivation in $44 \mathrm{~h}$ (Fig. 2). It was found through HPLC analysis of metabolites excreted into culture medium that expression of the $\operatorname{dav} A B$ genes in C. glutamicum BE resulted in conversion of L-lysine to
5AVA, whereas the non-engineered strain did not convert any L-lysine into 5AVA (Fig. 2).

Slightly decreased L-lysine production was observed in recombinant $C$. glutamicum $\mathrm{BE}$ strains expressing the $\operatorname{dav} A B$ genes, although L-lysine was still the major product in both engineered strains tested. Expression of the $\operatorname{dav} A B$ genes using the shuttle vector pEKEx1 (pJS30) was more effective at producing 5AVA than using pKCA212-MCS (pKCA212davAB) (Fig. 2). The $C$. glutamicum BE strain harboring pKCA212davAB produced $13.4 \mathrm{~g} / \mathrm{L}$ L-lysine (yield of $271.2 \mathrm{mmol} / \mathrm{mol}$ ) and $58 \mathrm{mg} / \mathrm{L} 5$ AVA (yield of $1.5 \mathrm{mmol} / \mathrm{mol}$ ), whereas the $C$. glutamicum BE strain harboring $\mathrm{pJS} 30$ produced $12.4 \mathrm{~g} / \mathrm{L}$ L-lysine (yield of $258.2 \mathrm{mmol} / \mathrm{mol}$ ) and $641 \mathrm{mg} / \mathrm{L} 5$ AVA (yield of $16.7 \mathrm{mmol} / \mathrm{mol}$ ) from glucose. These results demonstrate that heterologous expression of the $\operatorname{dav} A B$ genes from gram-negative $P$. putida correctly functioned to produce 5AVA from glucose using L-lysine as a 5AVA precursor in gram-positive C. glutamicum.

Although the C. glutamicum $\mathrm{BE}$ strain harboring pKCA212davAB or pJS30 successfully produced 5AVA 


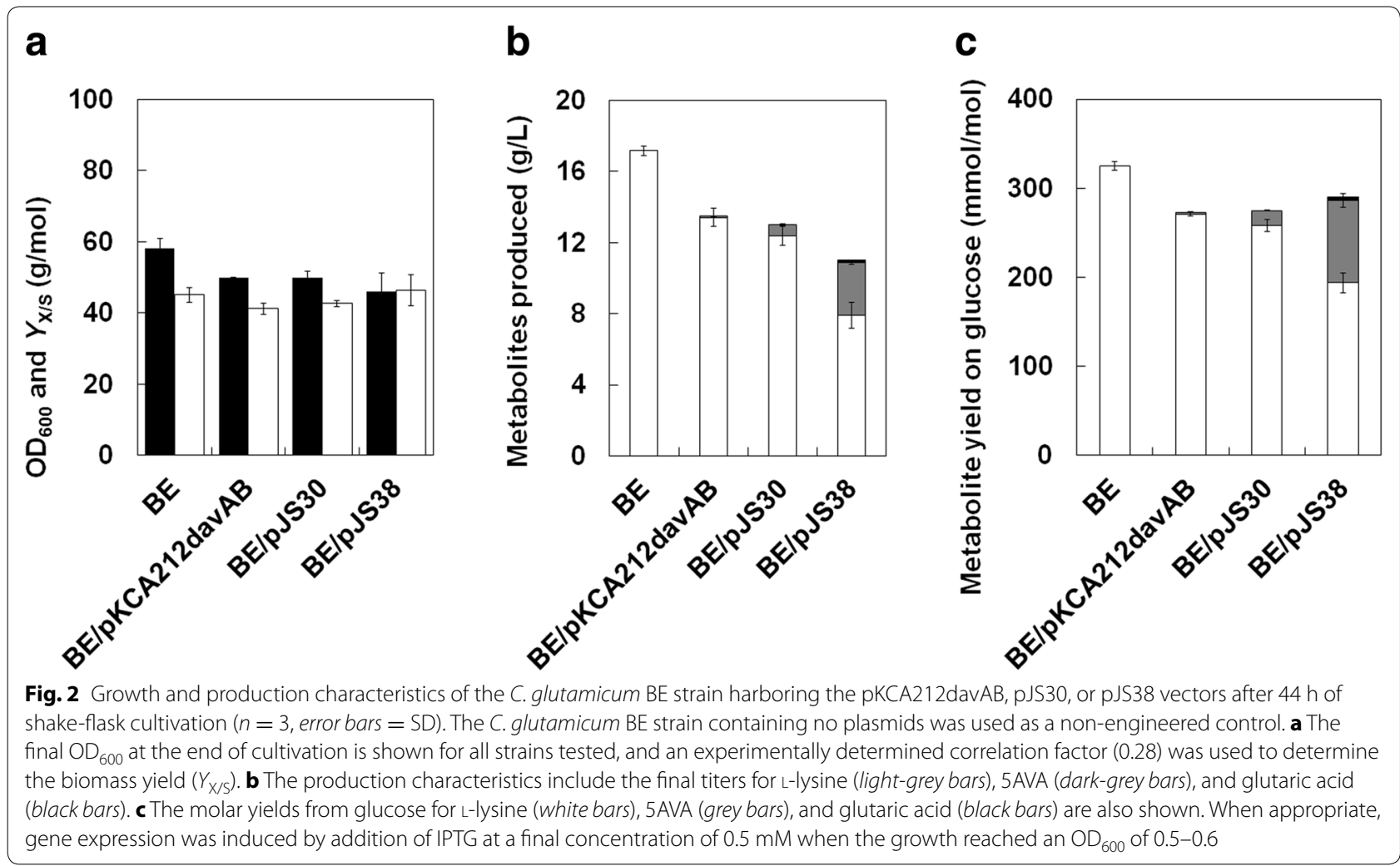

from glucose, most of L-lysine was not converted into 5AVA, which suggests that metabolic flux from L-lysine to 5AVA was still quite weak as a result of inefficient expression of the $\operatorname{dav} A B$ genes. Thus, we investigated whether 5AVA production could be enhanced by employing C. glutamicum codon-optimized $\operatorname{dav} A B$ genes. The $C$. glutamicum BE strain harboring pJS38, which expresses C. glutamicum codon-optimized davAB genes, produced 3.0 g/L 5AVA in flask cultivation, which represented an increase of almost $370 \%$ over that produced by the $C$. glutamicum BE strain harboring pJS30 (Fig. 2). However, $7.9 \mathrm{~g} / \mathrm{L}$ L-lysine still remained in the culture medium of C. glutamicum BE strain (pJS38). The yield for L-lysine obtained by C. glutamicum BE (pJS38) was $193.9 \mathrm{mmol} /$ mol glucose, whereas that for 5AVA was $92.3 \mathrm{mmol} / \mathrm{mol}$ glucose.

Notably, $0.14 \mathrm{mg} / \mathrm{L}$ glutaric acid was detected in the culture medium of C. glutamicum BE (pJS38), even though 5AVA aminotransferase and glutarate-semialdehyde dehydrogenase (encoded by $\operatorname{dav} T$ and $\operatorname{davD}$, respectively), which are the key enzymes for further conversion of 5AVA into glutaric acid using $\alpha$-ketoglutarate as an amine acceptor $[18,21]$, were not expressed in this strain. This result strongly suggests that endogenous enzymes homologous to 5AVA aminotransferase and glutarate-semialdehyde dehydrogenase might be involved in further conversion of 5AVA into glutaric acid in $C$. glutamicum.

\section{Examination of 5AVA production by engineered $C$. glutamicum strain expressing the $\operatorname{dav} A B$ genes under the control of the tac promoter in fed-batch fermentation} We then investigated the capability of C. glutamicum BE (pJS38) to produce 5AVA by fed-batch fermentation in a 5 -L fermentor (Fig. 3a, c) to examine its potential for large-scale production of 5AVA. During fed-batch cultivation of C. glutamicum BE (pJS38), L-lysine concentration reached $21.8 \mathrm{~g} / \mathrm{L}$ after $94 \mathrm{~h}$ of cultivation, and then decreased beyond this point. C. glutamicum BE (pJS38) produced $17.8 \mathrm{~g} / \mathrm{L}$ 5AVA in $191 \mathrm{~h}$, with an overall yield and productivity of $0.07 \mathrm{~g} / \mathrm{g}(107.3 \mathrm{mmol} / \mathrm{mol})$ and $0.09 \mathrm{~g} / \mathrm{L} / \mathrm{h}$, respectively (Fig. 3c). The total input of glucose was $790 \mathrm{~g}(4.4 \mathrm{~mol})$, and the total amount of produced 5AVA was $55.3 \mathrm{~g}(471 \mathrm{mmol})$, with the final volume of $3.1 \mathrm{~L}$. The maximum specific growth rate was $0.23 \mathrm{~h}^{-1}$, and the observed maximum specific productivity was $9.2 \mathrm{mg} / \mathrm{g} / \mathrm{h}$. Initial increases in L-lysine levels followed by a decrease in titer along with constant production of 5AVA indicated that L-lysine-production flux might be strong initially before slowing down in the latter half of cultivation. The maximum L-lysine-specific productivity was $56.7 \mathrm{mg} / \mathrm{g} / \mathrm{h}$ initially, but gradually decreased to 

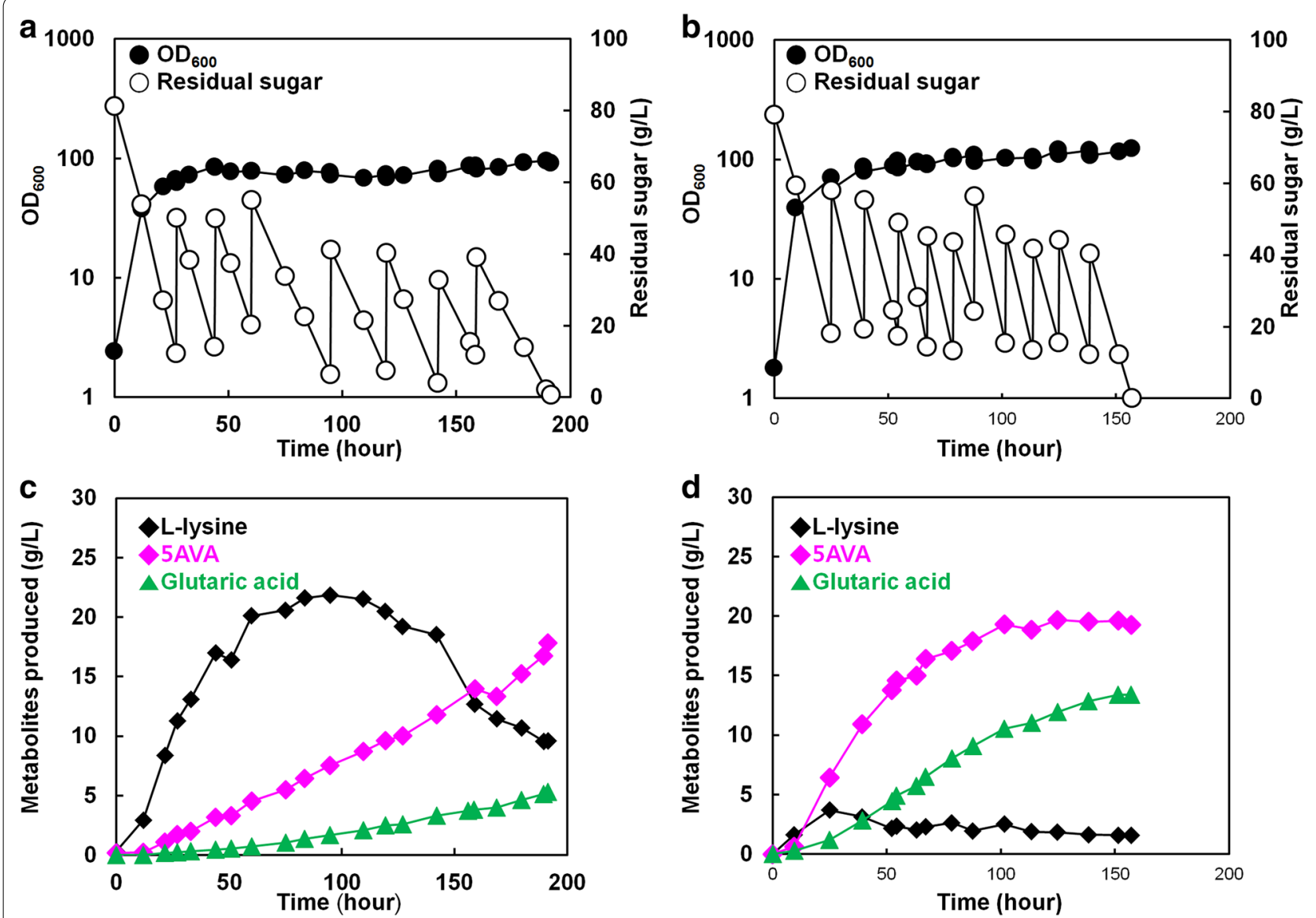

Fig. 3 Production of 5AVA from glucose by fed-batch cultures of (a, c) C. glutamicum BE (pJS38) and (b, d) C. glutamicum BE (p36davAB3). Characteristics of the fed-batch cultivation profile, including growth (filled circles, $\mathrm{OD}_{600}$ ), residual sugar (empty circles; $\mathrm{g} / \mathrm{L}$ ), L-lysine (filled diamonds), 5AVA (magenta diamonds), and glutaric acid (green triangles) production titers, are plotted against the cultivation time

zero. The amount of the major byproduct, glutaric acid, also increased steadily throughout the entire cultivation period until the concentration reached $5.3 \mathrm{~g} / \mathrm{L}$ at the end of cultivation (Fig. 3c).

The maximum $\mathrm{OD}_{600}$ reached was 95.4, corresponding to the measured dry cell weight concentration of $24.5 \mathrm{~g} / \mathrm{L}$, after $189 \mathrm{~h}$ of fermentation (Fig. 3a). These results demonstrated that C. glutamicum BE (pJS38) was able to successfully produce 5AVA from renewable resources in a laboratory-scale bioreactor. However, conversion of L-lysine toward 5AVA needs to be further enhanced through stronger expression of the $\operatorname{dav} A B$ genes.

\section{Construction of engineered C. glutamicum strain expressing the davAB genes under the control} of constitutive promoters to improve 5AVA production In addition to the tac promoter used in pEKEx1, promoters for SOD (NCgl2826; E.C. 1.15.1.1) and the transcription factor Tu (Tuf; Ncgl0480; E.C. 3.6.5.3) have also been widely used in metabolic engineering of C. glutamicum because of their capabilities to support strong gene expression at the chromosome level [34]. Although the sod promoter is known to exhibit weaker plasmidbased expression than the tac promoter [35], weak and medium-strength expression driven by constitutive promoters might be more effective than higher expression levels for producing chemicals of interest under different circumstances [15]. Moreover, use of the constitutive promoters circumvents the requirement for costly additives such as IPTG. Therefore, we replaced the $l a c I^{Q}$ gene and tac promoter in pJS38 with $\mathrm{P}_{\text {sod }}$ or $\mathrm{P}_{\text {tuf }}$ (Additional file 5: Table S1). These constructs were then introduced into the C. glutamicum BE strain, and their functions were investigated by flask cultivation. However, expression of the $\operatorname{davAB}$ genes under control of the sod promoter (pJS59) and tuf promoter (pJS60) did not result in higher 5AVA production relative to that produced by the parent construct, pJS38 containing the tac promoter (Figs. 2, 4). C. glutamicum BE (pJS59) and C. glutamicum BE (pJS60) produced 556 and $587 \mathrm{mg} / \mathrm{L}$ 5AVA, 
respectively, with no glutaric acid observed in the culture media after $44 \mathrm{~h}$ of flask cultivation.

We also investigated the newly designed synthetic promoter active in C. glutamicum, the H36 promoter [36], to see if it can possibly improve 5AVA production; it was successfully employed for the expression of glutamate decarboxylase (GAD) and lysine decarboxylase (LDC) in C. glutamicum strains, resulting in high-level production of gamma-aminobutyrate (GABA) and cadaverine, respectively [30, 37].

We replaced the $l a c I^{Q}$ and the tac promoter in pJS38 with the $\mathrm{P}_{\mathrm{H} 36}$ promoter to construct p36davAB2. However, cultivation of $C$. glutamicum $\mathrm{BE}$ harboring $\mathrm{p} 36 \mathrm{davAB} 2$ also did not improve 5AVA production, which resulted in production of $661 \mathrm{mg} / \mathrm{L}$ 5AVA under the same culture condition (Fig. 4). These results indicate that expression of the $\operatorname{dav} A B$ genes was still not strong enough to enable efficient conversion of L-lysine to 5AVA.

To continue exploring expression vector systems for possible improvement of 5AVA titer, we noticed that the strong H36 promoter originally developed with a different backbone vector, pCES208 [36, 38], might not be optimal for pEKEx1. Engineered C. glutamicum strains harboring a pCES208-based plasmid for expression of target genes under strong synthetic promoters, such as $\mathrm{H} 30$ and $\mathrm{H} 36$, have been reported to efficiently produce GABA and cadaverine from renewable resources [30, 37]. Therefore, we transferred codon-optimized versions of the $\operatorname{davAB}$ genes into the pCES208 vector system.
The new construct, p36davAB1, was further modified by inserting a $\mathrm{His}_{6}$-Tag into the $\mathrm{N}$-terminal of $\operatorname{davA}$ gene, resulting in p36davAB3. This was done because there have been reports showing that His $_{6}$-tagged constructs can sometimes be expressed more efficiently [39, 40]. These constructs were transformed into the C. glutamicum BE strain and assessed by flask cultivation. Whereas C. glutamicum BE (p36davAB1) produced only $0.4 \mathrm{~g} / \mathrm{L}$ 5AVA along with $11.7 \mathrm{~g} / \mathrm{L}$ L-lysine, C. glutamicum BE (p36davAB3) produced $6.9 \mathrm{~g} / \mathrm{L}$ 5AVA, with $5.5 \mathrm{~g} / \mathrm{L}$ L-lysine remaining unconverted (Fig. 5). The 5AVA concentration obtained represents a $130 \%$ increase over that (Fig. 2) obtained with C. glutamicum BE (pJS38). Interestingly, the construct containing the $\mathrm{His}_{6}$-tagged variant produced substantially more 5AVA compared to that produced using the construct lacking the His-tag, possibly because of the improved stability afforded by the $5^{\prime}$ modification, which resulted in higher expression of the $\operatorname{dav} A B$ genes in the recombinant $C$. glutamicum $\mathrm{BE}$ strain (Additional file 1: Figure S1). Comparison of mRNA folding energies $(\Delta G)$ with the RNA secondary structure prediction program Mfold (http://unafold.rna. albany.edu/?q=mfold/download-mfold) suggested that the $\Delta \mathrm{G}$ for the first 30 nucleotides starting from the +1 site of the $\mathrm{H} 36$ promoter in p36davAB2 is $-6.00 \mathrm{kcal} /$ mol, which is much lower than $\Delta G$ of $-0.06 \mathrm{kcal} / \mathrm{mol}$ obtained in p36davAB3. The higher $\triangle G$ in p36davAB3 indicates that less stable mRNA produced by p36davAB3 might allow the translation machinery to bind more easily than much stable mRNA produced by p36davAB2.
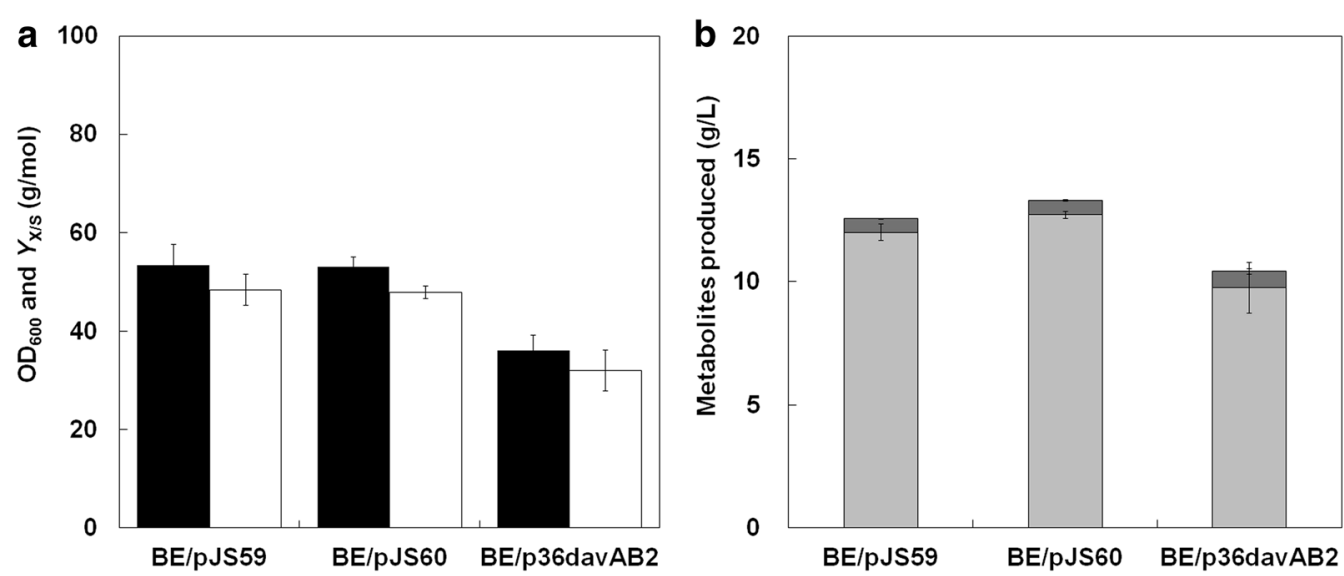

Fig. 4 Growth and production characteristics of the C. glutamicum BE strain harboring the pJS59, pJS60, or p36davAB2 vector after 44 h of shakeflask cultivation ( $n=3$, error bars $=$ SD). The C. glutamicum BE strain containing no plasmids was used as a non-engineered control. a The final $\mathrm{OD}_{600}$ at the end of cultivation is shown for all strains tested, and an experimentally determined correlation factor $(0.28)$ was used to determine the biomass yield $\left(Y_{X / S}\right)$. b The production characteristics include the final titers for L-lysine (light-grey bars), 5AVA (dark-grey bars), and glutaric acid (black bars) 

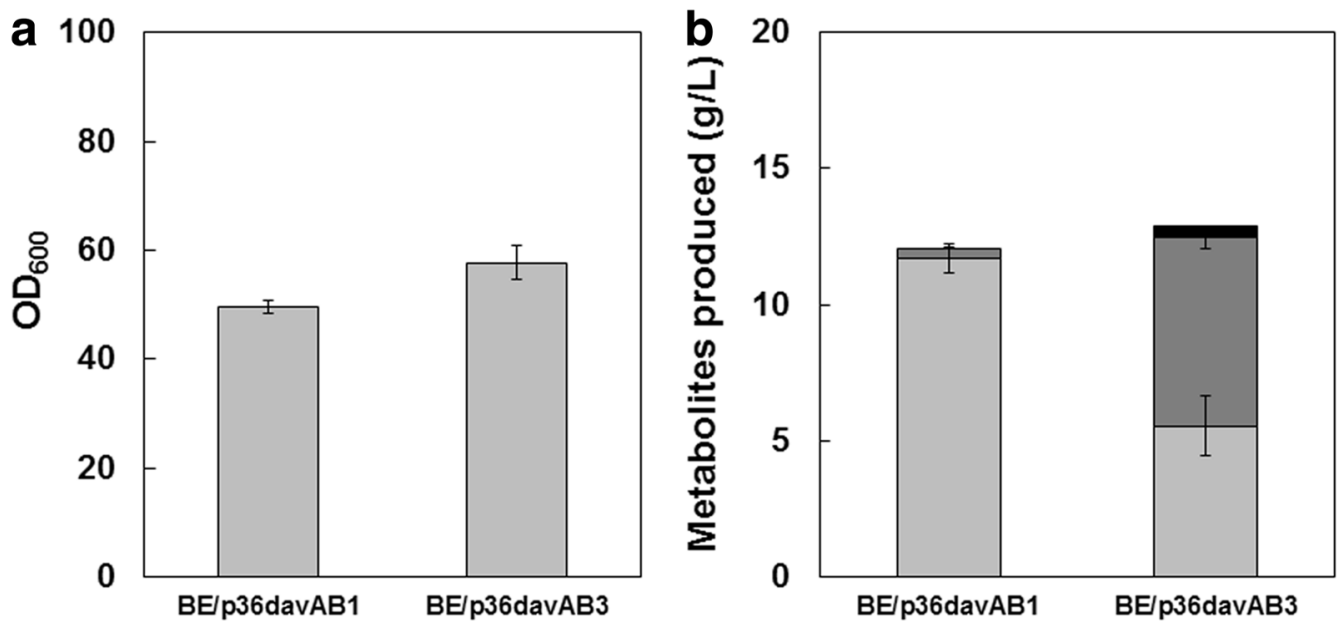

Fig. 5 Growth and production characteristics of the C. glutamicum BE strain harboring p36davAB1 or p36davAB3 after 44 h of shake-flask cultivation $\left(n=3\right.$, error bars $=S D$ ). $\mathbf{a}$ The final $\mathrm{OD}_{600}$ at the end of cultivation is shown for the strains tested. $\mathbf{b}$ The production characteristics include the final titers for L-lysine (light-grey bars), 5AVA (dark-grey bars), and glutaric acid (black bars)

Examination of 5AVA production by engineered $C$. glutamicum expressing the dav $A B$ genes under the control of the strong $\mathrm{H} 36$ promoter in fed-batch fermentation

Having achieved improved 5AVA production in flask culture, fed-batch culture of C. glutamicum BE (p36davAB3) was performed next in a 5-L fermentor. C. glutamicum $\mathrm{BE}$ (p36davAB3) produced $19.7 \mathrm{~g} / \mathrm{L}$ 5AVA in $157 \mathrm{~h}$, with the overall yield and productivity of $0.08 \mathrm{~g} / \mathrm{g}$ and $0.16 \mathrm{~g} / \mathrm{L} / \mathrm{h}$, respectively (Fig. $3 \mathrm{~d}$ ). This strain also accumulated $13.4 \mathrm{~g} / \mathrm{L}$ glutaric acid as a byproduct at the end of the cultivation. On the other hand, L-lysine accumulation decreased significantly compared to that observed with C. glutamicum BE (pJS38). L-Lysine accumulated to $3.7 \mathrm{~g} / \mathrm{L}$ in $25 \mathrm{~h}$, but production remained between 1 and $2 \mathrm{~g} / \mathrm{L}$ over the entire cultivation period (Fig. 3d). Citric acid was another major byproduct, but its concentration remained at $\sim 1 \mathrm{~g} / \mathrm{L}$ throughout cultivation. Notably, the production patterns observed during fed-batch fermentation were different from those observed during flask cultivation. Although large portions of L-lysine remained unconverted at the end of the flask cultivation, very little L-lysine remained in fed-batch fermentation. This indicates that control of $\mathrm{pH}$ and provision of sufficient air streams were beneficial for 5AVA production and provided better results during fed-batch fermentation. A sufficient air supply is important for cultivation because lack of sufficient air can result in accumulation of substantial concentrations of lactic and acetic acids in the fermentation broth $[30,41]$. These byproducts were not observed in our cultivation conditions, contrary to previous reports. These results suggest that the strategy combining improved expression of the $\operatorname{dav} A$ gene fused with $\mathrm{His}_{6}$-Tag at its N-Terminal and the $\operatorname{davB}$ gene as an operon under control of the strong synthetic $\mathrm{H}_{36}$ promoter was successful in directing most of the L-lysine pool toward 5AVA, resulting in efficient production of 5AVA.

Construction of an engineered C. glutamicum gabT mutant for enhanced production of 5AVA with greatly reduced glutaric acid production

While $19.7 \mathrm{~g} / \mathrm{L}$ of 5AVA could be produced by fed-batch cultivation of C. glutamicum BE (p36davAB3), glutaric acid, a major byproduct, was still produced to a relatively high concentration (up to $13.4 \mathrm{~g} / \mathrm{L}$ ). In order to further enhance 5AVA production, conversion of 5AVA into glutaric acid should be minimized. However, no enzyme responsible for converting 5AVA into glutaric acid is known in C. glutamicum. Thus, we performed moleculardocking simulations, which suggested possible interactions between endogenous GabT and 5AVA (Additional file 2: Figure S2, Additional file 3: Figure S3). GabT shares homology (60\% by primary peptide structure) with 4-aminobutyrate aminotransferase (SGR_1829) in Streptomyces griseus, which exhibits $60 \%$ relative aminotransfer activity for 5AVA [42]. Although the pyridoxal phosphate moiety was in the correct orientation and position, the orientation of bound 5AVA was twisted, possibly because of the larger size of the substrate being accommodated in the active site. Additionally, the enzyme also shared high homology (Additional file 3: Figure S3) with P. putida DavT, which binds 5AVA as its natural substrate (Additional file 4: Figure S4). The major difference in active sites between GabT and DavT is that 
DavT contains a glutamine residue (Gln80) rather than a methionine residue, enabling accommodation of the $\omega$-amino group in the binding pocket (Additional file 3: Figure S3). However, GabT from S. griseus, even with the methionine residue at this position, is sufficiently promiscuous to accept 5AVA as a substrate [42]. Thus, we could conclude from the docking simulations that the endogenous C. glutamicum GabT might accommodate 5AVA as a substrate for aminotransfer reactions, leading to the formation of glutaric acid.

Based on the above results, the gabT gene (E.C. 2.6.1.19, encoding 4-aminobutyrate aminotransferase, Ncgl0462) was deleted from the chromosome of C. glutamicum BE to construct C. glutamicum AVA2. C. glutamicum AVA2 produced $17.5 \mathrm{~g} / \mathrm{L}$ of L-lysine by flask cultivation in $44 \mathrm{~h}$, with no residual 5AVA detected (Fig. 6). This result

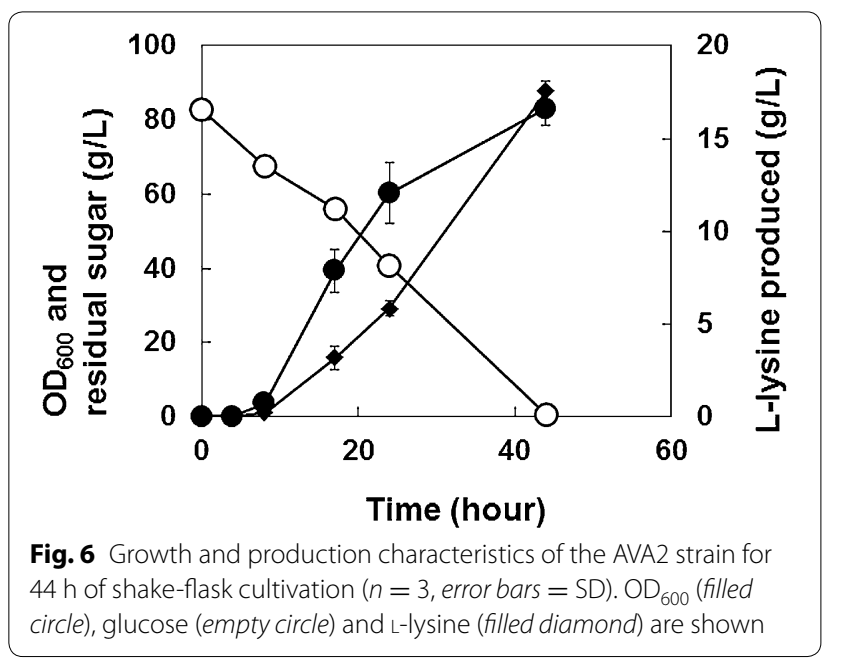

suggests that deletion of the $g a b T$ gene did not inhibit cell growth and L-lysine production. Plasmid p36davAB3 was then transformed into C. glutamicum AVA2 to assess 5AVA production. Fed-batch cultivation of engineered C. glutamicum AVA2 (p36davAB3) in a 5-L fermenter resulted in production of $33.1 \mathrm{~g} / \mathrm{L}$ 5AVA with greatly reduced glutaric acid $(2.0 \mathrm{~g} / \mathrm{L})$ and L-lysine $(648.3 \mathrm{mg} / \mathrm{L})$ at the end of cultivation. The overall yield and productivity obtained were $0.1 \mathrm{~g} / \mathrm{g}$ glucose $(163.1 \mathrm{mmol} / \mathrm{mol})$ and $0.22 \mathrm{~g} / \mathrm{L} / \mathrm{h}$, respectively (Fig. 7). Cells grew to an $\mathrm{OD}_{600}$ of 134 in $153 \mathrm{~h}$, with a measured dry cell weight of $36.1 \mathrm{~g} / \mathrm{L}$, with the maximum specific growth rate was $0.4 \mathrm{~h}^{-1}$. The maximum specific 5AVA productivity was $65.8 \mathrm{mg} / \mathrm{g} / \mathrm{h}$, which gradually decreased to $22.1 \mathrm{mg} / \mathrm{g} / \mathrm{h}$ at the end of cultivation. Additionally, the L-lysine concentration peaked at $28 \mathrm{~h}$, but remained as low as $1 \mathrm{~g} / \mathrm{L}$ for the remainder of the cultivation. As expected, gabT deletion resulted in a significant decrease in glutaric acid production compared to that observed in the parent strain. However, the continued presence of glutaric acid in the culture broth suggests that unknown aminotransferases still remain in C. glutamicum that are capable of converting 5AVA to glutaric acid, although at lower efficiencies than GabT.

\section{Conclusions}

In this study, we report development of engineered $C$. glutamicum strains for the production of 5AVA from glucose. Expression of two key enzymes, lysine 2-monooxygenase and delta-aminovaleramidase, was systematically optimized by examining different promoters, origins of replication, codon usage of the $\operatorname{dav} A B$ genes, and even $5^{\prime}$ modification of the davA gene with a His-tag, all of which
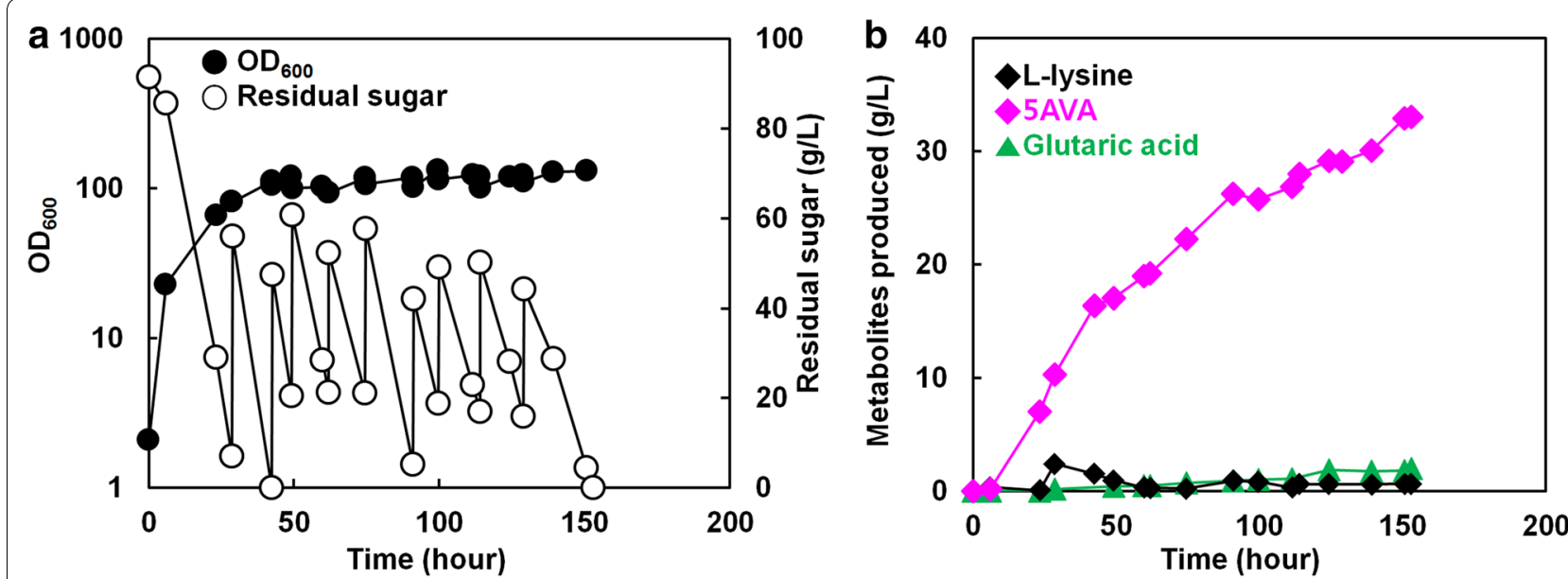

Fig. 7 Fed-batch cultivation of C. glutamicum AVA2 harboring p36davAB3 for the production of 5AVA in laboratory-scale bioreactor from glucose. a Characteristics of the fed-batch cultivation profile including growth (filled circles, $\mathrm{OD}_{600}$ ), residual sugar (empty circles; $\mathrm{g} / \mathrm{L}$ ) and $\mathbf{b}$ production titers of products including L-lysine (dark diamonds), 5AVA (magenta diamonds), and glutaric acid (green triangles) are plotted against the cultivation time 
were found to be important for determining the optimal and stable plasmid-based expression of the $\operatorname{dav} A B$ genes in C. glutamicum. In addition, production of a major byproduct, glutaric acid, could be significantly reduced by identifying previously unknown enzyme GabT responsible for converting 5AVA to glutaric acid and deleting the corresponding gene from the chromosome. Fed-batch cultivation of the final engineered C. glutamicum AVA2 strain harboring p36davAB3 produced $33.1 \mathrm{~g} / \mathrm{L}$ 5AVA with greatly reduced glutaric acid $(2.0 \mathrm{~g} / \mathrm{L})$. The metabolically engineered C. glutamicum strains developed in this study should be useful for enhanced fermentative production of the novel C5 platform chemical, 5AVA, from renewable resources such as glucose.

\section{Methods}

\section{Strains and plasmids}

All bacterial strains and plasmids used in this study are listed in Additional file 5: Table S1. All DNA manipulations were performed following standard procedures [43]. Primers used in this study (Additional file 6: Table S2) were synthesized at Bioneer (Daejeon, Korea). C. glutamicum BE (KCTC 12390BP) was used as the base strain for 5AVA production. Polymerase chain reaction (PCR) was performed with the C1000 Thermal Cycler (BioRad, Hercules, CA, USA). The general PCR condition for amplifications of target genes using primer sets listed in Additional file 6: Table $\mathrm{S} 2$ is as follows: 1 cycle of $95^{\circ} \mathrm{C}$ for 5 min; 30 cycles of $94{ }^{\circ} \mathrm{C}$ for $30 \mathrm{~s}, 52{ }^{\circ} \mathrm{C}$ for $30 \mathrm{~s}, 72{ }^{\circ} \mathrm{C}$ for $1 \mathrm{~min} 30 \mathrm{~s}$; and a final extension of $72{ }^{\circ} \mathrm{C}$ for $5 \mathrm{~min}$. The final reaction volume is $20 \mu \mathrm{L}$. The in-house-developed C. glutamicum shuttle vector pKCA212-MCS was constructed by cloning the origin of replication of the cryptic plasmid pCC1 [33] into pKA212-MCS at the AatII and $X$ hoI sites. The origin of replication of pCC1 was synthesized by GenScript (http://www.genscript.com) based on the reported sequence. Plasmid pKA212-MCS was constructed by replacing the chloramphenicol-resistance gene of pKA312-MCS [11] with a kanamycin-resistance gene obtained from pZA21-MCS (http://www.expressys. com) by restriction digest with AatII and SpeI. The davAB genes from pKE112-DavAB $[20,21]$ were restrictiondigested and ligated into pKCA212-MCS to construct pKCA212davAB using the same restriction enzyme sites (EcoRI/KpnI, KpnI/BamHI). A 16-bp untranslated region (tttcacacaggaaaca) containing a ribosome-binding site was present between the two genes for $\operatorname{dav} B$ expression. The same genes were also cloned into pEKEx1 to construct pJS30. The codon-optimized versions of $\operatorname{dav} A B$ genes (Additional file 7: Table S3) with preferred codon usage in C. glutamicum were synthesized by Bioneer (Daejeon, Korea) and cloned into the EcoRI/BamHI restriction enzyme sites in pEKEx1 to yield pJS38.
To construct promoter variants of pEKEx1, promoterless pEKEx 1 was created by removing the tac promoter and the initial $778 \mathrm{bp}$ of the coding sequence of the $\mathrm{Lacl}^{Q}$ gene from pEKEx1 by restriction digestion with EcoRV/EcoRI. The desired promoters were similarly designed as previously described [5, 34, 44] and inserted into the promoterless pEKEx 1 vector. The region $250 \mathrm{bp}$ upstream of the start codon for the superoxide dismutase gene (NCgl2826, E.C. 1.15.1.1) was amplified by polymerase chain reaction (PCR) from C. glutamicum ATCC 13032 chromosome using primers Psod_F_EcoRV and Psod_R_EcoRI, and then digested and cloned into the $E c o R V / E c o R I$ sites of the promoterless pEKEx1 vector to construct pJS57. The 248-bp sequence upstream of the start codon for the gene encoding the elongation factor $\mathrm{Tu}$ (Ncgl0480, E.C. 3.6.5.3) was amplified by PCR from C. glutamicum ATCC 13032 chromosome using the primers Ptuf_F_EcoRV (v2) and Ptuf_R_EcoRI, and then digested and cloned into the promoterless pEKEx1 vector to yield pJS58. The codon-optimized davAB genes from pJS38 were restriction-digested with $E c o \mathrm{RI} / B a m \mathrm{HI}$ and cloned into the pJS57 and pJS58 vectors at the EcoRI/BamHI restriction enzyme sites to make pJS59 and pJS60, respectively.

Plasmid p36davAB2 was constructed from pEKEx1 by cloning the codon-optimized $\operatorname{dav} A B$ genes. Promoterless pEKEx1 was constructed by methods similar to those described in the previous paragraph, except that the genes were cloned into the EcoRV/PstI restriction sites of the vector. The $\mathrm{P}_{\mathrm{H} 36}$ promoter was amplified by PCR using the JW02H-F and JW02H-R primers from pCES208H36GFP, and the fragments were restrictiondigested with EcoRV/EcoRI. A second round of PCR using primers JW02AB-F and JW02AB-R from pJS38 generated codon-optimized $\operatorname{dav} A B$ gene fragments that were restriction-digested with EcoRI/PstI. The resulting products were then ligated into the EcoRV/PstI restriction sites of the promoterless pEKEx1 vector to yield p36davAB2.

Plasmid p36davAB1 was constructed from pCES208 by cloning the codon-optimized $\operatorname{dav} A B$ genes. Products from the first round of PCR using primers JW01A-F and JW01A-R were used for amplification of the $\operatorname{davA}$ gene, which was then restriction-digested with $B a m \mathrm{HI} / S f \mathrm{I}$. The second round of PCR used primers JW01B-F and JW01B-R to amplify the $\operatorname{davB}$ gene, which was then restriction-digested with NotI. These fragments were cloned into the pCES208H36GFP vector [36] by replacing the egfp gene to yield p36davAB1.

Plasmid p36davAB3 was constructed from the pCES208H36EGFP vector [36]. The codon-optimized $\operatorname{davA}$ gene fused with $\mathrm{His}_{6}$-Tag at its $\mathrm{N}$-Terminal was amplified using primers JW03A-F and JW01A-R and 
restriction-digested with BamHI and SfiI. The codonoptimized $\operatorname{dav} B$ gene was amplified using primers JW01B-F and JW03B-R and restriction-digested with Not I. The two products were then cloned into the pCES208H36EGFP vector by replacing the egfp gene to construct p36davAB3.

Plasmid pJS113 beta was constructed from the pK19mobsacB vector [45]. Primers 113 i1F beta and 113 i1R beta were used to PCR-amplify the upstream region and a portion of the gabT gene from C. glutamicum. Primers $113 \mathrm{i} 2 \mathrm{~F}$ beta and $113 \mathrm{i} 2 \mathrm{R}$ beta were then used to PCR-amplify the downstream region and a portion of the gabT gene of C. glutamicum. The two PCR products were joined by a third PCR using primers $113 \mathrm{i} 1 \mathrm{~F}$ beta and 113 $\mathrm{i} 2 \mathrm{R}$ beta. The final PCR product was cloned into the PstIdigested pK19mobsacB to make pJS113 beta. pJS113 beta was subsequently used to disrupt the $g a b T$ gene in the $C$. glutamicum $\mathrm{BE}$ chromosome, resulting in the strain $C$. glutamicum AVA2. This in-frame deletion left a 330-bp deletion in the 280-609 region of the 1347-bp gabT gene.

E. coli $\mathrm{DH} 5 \alpha$ and TOP10 strains (Additional file 5: Table S1) were used for general cloning purposes. All constructed plasmids introduced into C. glutamicum, except for pJS113 beta, were prepared in unmethylated form using the methylation-deficient $E$. coli JM110 strain (Stratagene; Agilent Technologies, Santa Clara, CA, USA). pJS113 beta was propagated in C. glutamicum by bacterial conjugation using E. coli $\mathrm{S} 17-1$ as a donor [45]. Plasmids were introduced via electroporation as previously described [46]. Cells were transferred to a microcuvette and electroporated using a micropulser. Cells were transformed with about $2 \mu \mathrm{g}$ of DNA by electroporation $(1.8 \mathrm{~V}$ and $400 \Omega)$. Pre-chilled preculture medium $(900 \mu \mathrm{L})$ was added and the transformed cells were allowed for growth recovery for $2 \mathrm{~h}$ without shaking in a $30{ }^{\circ} \mathrm{C}$ incubator. The transformed cells were then spread onto the agar plates containing kanamycin as a selective marker.

\section{Culture media}

Cells were cultured in media described below, the compositions of which were modified from previous reports $[34,43]$. The pre-culture medium for shake-flask cultivation consisted of $10 \mathrm{~g} / \mathrm{L}$ beef extract (BD Bacto, Franklin Lakes, NJ, USA), $40 \mathrm{~g} / \mathrm{L}$ brain-heart infusion (BD Bacto), $20 \mathrm{~g} / \mathrm{L}$ D-sorbitol, and $10 \mathrm{~g} / \mathrm{L}$ glucose [41]. The flask culture medium ( $\mathrm{pH}$ 7.2) consisted of $80 \mathrm{~g} / \mathrm{L}$ glucose, $1 \mathrm{~g} / \mathrm{L}$ $\mathrm{MgSO}_{4}, 1 \mathrm{~g} / \mathrm{L} \mathrm{K}{ }_{2} \mathrm{HPO}_{4}, 1 \mathrm{~g} / \mathrm{L} \mathrm{KH_{2 }} \mathrm{PO}_{4}, 1 \mathrm{~g} / \mathrm{L}$ urea, $20 \mathrm{~g} / \mathrm{L}$ $\left(\mathrm{NH}_{4}\right)_{2} \mathrm{SO}_{4}, 10 \mathrm{~g} / \mathrm{L}$ yeast extract, $100 \mu \mathrm{g} / \mathrm{L}$ biotin, $10 \mathrm{mg} / \mathrm{L}$ $\beta$-alanine, $10 \mathrm{mg} / \mathrm{L}$ thiamine $\mathrm{HCl}, 10 \mathrm{mg} / \mathrm{L}$ nicotinic acid,
$1.3 \mathrm{mg} / \mathrm{L}\left(\mathrm{NH}_{4}\right)_{6} \mathrm{MoO}_{24}, 40 \mathrm{mg} / \mathrm{L} \mathrm{CaCl} 2,10 \mathrm{mg} / \mathrm{L} \mathrm{FeSO}_{4}$, $10 \mathrm{mg} / \mathrm{L} \mathrm{MnSO}_{4}, 5 \mathrm{mg} / \mathrm{L} \mathrm{CuSO}_{4}, 10 \mathrm{mg} / \mathrm{L} \mathrm{ZnSO}_{4}$, and $5 \mathrm{mg} / \mathrm{L} \mathrm{NiCl}_{2}$.

For fermentation experiments, the seed medium $(\mathrm{pH}$ 7.0) consisted of $20 \mathrm{~g} / \mathrm{L}$ glucose, $1 \mathrm{~g} / \mathrm{L} \mathrm{MgSO}, 10 \mathrm{~g} / \mathrm{L}$ beef extract, $1 \mathrm{~g} / \mathrm{L} \mathrm{K}_{2} \mathrm{HPO}_{4}, 1 \mathrm{~g} / \mathrm{L} \mathrm{KH}_{2} \mathrm{PO}_{4}, 0.5 \mathrm{~g} / \mathrm{L}$ urea, $10 \mathrm{~g} / \mathrm{L}$ yeast extract, $100 \mu \mathrm{g} / \mathrm{L}$ biotin, $200 \mu \mathrm{g} / \mathrm{L}$ thiamine $\mathrm{HCl}, 10 \mathrm{mg} / \mathrm{L} \mathrm{FeSO}_{4}$, and $10 \mathrm{mg} / \mathrm{L} \mathrm{MnSO}_{4}$. The fermentation medium $(1.8 \mathrm{~L})$ contained per liter: $160 \mathrm{~g}$ of glucose, $2 \mathrm{~g}$ of $\mathrm{MgSO}_{4}, 2 \mathrm{~g}$ of $\mathrm{K}_{2} \mathrm{HPO}_{4}, 2 \mathrm{~g}$ of $\mathrm{KH}_{2} \mathrm{PO}_{4}, 2 \mathrm{~g}$ of urea, $40 \mathrm{~g}$ of $\left(\mathrm{NH}_{4}\right)_{2} \mathrm{SO}_{4}, 20 \mathrm{~g}$ of yeast extract, $50 \mathrm{mg}$ of $\mathrm{CaCl}_{2}, 50 \mu \mathrm{g}$ of biotin, $20 \mathrm{mg}$ of $\beta$-alanine, $20 \mathrm{mg}$ of thiamine $\mathrm{HCl}, 20 \mathrm{mg}$ of nicotinic acid, $1.3 \mathrm{mg}$ of $\left(\mathrm{NH}_{4}\right)_{6} \mathrm{Mo}_{7} \mathrm{O}_{24}, 10 \mathrm{mg}$ of $\mathrm{FeSO}_{4}, 10 \mathrm{mg}$ of $\mathrm{MnSO}_{4}, 5 \mathrm{mg}$ of $\mathrm{CuSO}_{4}, 10 \mathrm{mg}$ of $\mathrm{ZnSO}_{4}, 5 \mathrm{mg}$ of $\mathrm{NiCl}_{2}$, and $1 \mathrm{~mL}$ of antifoam reagent (Antifoam 204; Sigma-Aldrich, St. Louis, MO, USA). Each feeding solution $(200 \mathrm{~mL})$ contained $90 \mathrm{~g}$ of glucose.

\section{Flask cultivation}

Stock cells stored in glycerol were used to inoculate 5 -mL pre-cultures, which were grown at $30{ }^{\circ} \mathrm{C}$ with shaking at $200 \mathrm{rpm}$ in an incubator (JSSI-300C; JS Research Inc., Gongju, Korea) for 17-18 h. Cells suspended in $250-\mu \mathrm{L}$ aliquots of pre-culture were harvested by centrifugation (Centrifuge 5415 D; Eppendorf, Hamburg, Germany) and transferred to a $25-\mathrm{mL}$ primary culture in autoclaved 300-mL baffled Erlenmeyer flasks, each containing $1.5 \mathrm{~g}$ of $\mathrm{CaCO}_{3}$ to maintain the $\mathrm{pH}$ at $\sim 7.0$ during cultivation. Primary cultures were grown with shaking in an incubator for $44 \mathrm{~h}$. When appropriate, isopropyl- $\beta$-D-thiogalactopyranoside (IPTG) at a final concentration of $0.5 \mathrm{mM}$ was used to induce gene expression during the early log phase $\left(\mathrm{OD}_{600}=0.5-0.6\right)$, with $25.0 \mu \mathrm{g} / \mathrm{mL}$ kanamycin added for selective pressure (Ravasi et al. [35]).

\section{Fed-batch fermentation}

Stock cells stored in glycerol were used to inoculate 5.0$\mathrm{mL}$ pre-cultures, which were grown at $30^{\circ} \mathrm{C}$ with shaking in an incubator for 17-18 h. Two 1-mL samples of the pre-culture were transferred to two 1-L Erlenmeyer flasks, each containing $100 \mathrm{~mL}$ of seed medium, and grown with shaking $(200 \mathrm{rpm})$ in a $30^{\circ} \mathrm{C}$ incubator for 19-20 h. The entire seed culture $(200 \mathrm{~mL})$ was added as the inoculum to the $1.8-\mathrm{L}$ primary culture in a fermenter (initial $\mathrm{OD}_{600}=1.5-2.0$ in $2 \mathrm{~L}$ ). IPTG at a final concentration of $1 \mathrm{mM}$ and kanamycin $(25.0 \mu \mathrm{g} / \mathrm{L})$ were also added during fermentation inoculation. A NBS BioFlo 3000 fermenter system (New Brunswick Scientific, 
Edison, NJ, USA) equipped with a 6.6-L jar was used for all fed-batch cultivation experiments. The $\mathrm{pH}$ was maintained at 7.0 by addition of $28 \%(\mathrm{v} / \mathrm{v})$ ammonia solution (Junsei Chemical Co., Ltd., Tokyo, Japan). Temperature and agitation were maintained at $30{ }^{\circ} \mathrm{C}$ and $600 \mathrm{rpm}$, respectively, by a proportional-integral-derivative controller throughout the entire cultivation period. The aeration rate was maintained at $1 \mathrm{~L} / \mathrm{L} / \mathrm{min}$. Foaming was suppressed by addition of 1:10 diluted antifoam 204 (Sigma-Aldrich). Feeding solution $(200 \mathrm{~mL})$ was manually added each time the residual glucose level decreased to $<20 \mathrm{~g} / \mathrm{L}$.

\section{Analytical procedures}

Two high-performance liquid chromatography (HPLC) systems, Agilent 1100 (Agilent Technologies) and Waters Breeze 2 (Waters Corporation, Milford, MA, USA), were used to determine the metabolite concentration in the culture broth. For detection of amino compounds, the supernatant of the culture samples was reacted with $o$-phthaldehyde as previously described [13] prior to injection into the Eclipse Zorbax-AAA column (Agilent Technologies). Linear gradients of mobile phase $\mathrm{A}$ $\left[10 \mathrm{mM} \mathrm{Na}_{2} \mathrm{HPO}_{4}, 10 \mathrm{mM} \mathrm{Na}_{2} \mathrm{~B}_{4} \mathrm{O}_{7} \cdot 10 \mathrm{H}_{2} \mathrm{O}\right.$, and $8 \mathrm{mg} / \mathrm{L}$ $\mathrm{NaN}_{3}$ (pH 7.2)] and mobile phase B (methanol, acetonitrile, and water at a volumetric ratio of 45:45:10) were used to separate the amino acids in the column. Borate buffer (0.4 M; pH 10.2) was used as a buffering agent rather than $\mathrm{pH} 9.0$ buffer as previously described [13]. The derivatized compounds were detected using a diodearray detector at $338 \mathrm{~nm}$. The column temperature was set to $25{ }^{\circ} \mathrm{C}$, and the flow rate of the pump was set to $0.640 \mathrm{~mL} / \mathrm{min}$. The following gradient was applied for resolving the compounds: $0-0.5 \mathrm{~min}, 0 \% \mathrm{~B}$; $0.5-18 \mathrm{~min}$, a linear gradient of $B$ from 0 to $57 \%$; 18-26 min, a linear gradient of B from 57 to $100 \%$; 26-31.8 min, $100 \%$ B; 31.8-31.9 min, a linear gradient of B from 100 to $0 \%$; 31.9-32 $\mathrm{min}, 0 \%$ by volume. Glutaric acid was detected using the Waters Breeze 2 HPLC system (Waters Corporation) with a MetaCarb 87H column (Varian; Crawford Scientific, Strathaven, UK) and a constant flow of sulfuric acid solution at $0.5 \mathrm{~mL} / \mathrm{min}$. The Waters Breeze 2 system included an isocratic pump (Waters 1515; Waters Corporation), a refractive index detector (Waters 2414; Waters Corporation), and an autosampler (Waters 2707; Waters Corporation).

Cell growth was monitored by measuring the $\mathrm{OD}_{600}$ with an Ultrospec 3000 spectrophotometer (Amersham
Biosciences, Uppsala, Sweden). The correlation factor $\left(0.28 \mathrm{~g}\right.$ of dry weight of cells per L per $\mathrm{OD}_{600}$ of 1$)$ was experimentally determined and used for biomass concentration calculation of flask-cultivated cells. This correlation factor was in agreement with a previously reported value [47]. Glucose concentration was measured using a 2700 biochemistry analyzer (YSI, Yellow Springs, OH, USA). When necessary, diluted $\mathrm{HCl}$ solution was used to neutralize $\mathrm{CaCO}_{3}$ in the cultivation media.

\section{Molecular docking simulation}

Molecular docking simulations were performed using Autogrid and Autodock 4.2.5.1 software [48]. Gasteiger charges and hydrogen atoms were added using AutoDockTools 1.5.6. A Lamarckian genetic algorithm with default parameters was used, and no peptide residues were kept flexible. The docking grid was set to encompass the catalytic pocket, but not the entire enzyme. For docking of the natural substrate of 4-aminobutyrate aminotransferase, the substrate molecules were separately saved from a known structure (PDB ID: 4ATQ) [49] as a single molecule in the form of an external aldimine and used as a ligand. For docking with 5AVA aminotransferase, pyridoxal phosphate and 5AVA in the form of an external aldimine were used as the ligand. Torsion about the bond between the pyridine moiety of the pyridoxal phosphate and the Schiff base was not allowed during docking. The docking results were visualized using PyMol 1.6 (https:// www.pymol.org/pymol) without additional hydrogen atoms.

\section{Molecular modeling}

Homology modeling was carried out with SWISSMODEL [50]. 4-Aminobutyrate aminotransferase (E.C. 2.6.1.19) of C. glutamicum was homology modeled using the same enzyme from $A$. aurescens (PDB ID: 4ATQ chain B) [49] as a template. A minor correction was applied for this model (Additional file 2: Figure S2) based on a different enzyme structure (PDB ID: 3LV2). The same enzyme from S. griseus was homology modeled using that from Mycobacterium smegmatis (PDB ID: 3Q8 $\mathrm{N}$ chain $\mathrm{D}$ ) as a template. 5-Aminovalerate aminotransferase (E.C. 2.6.1.48) of P. putida KT2440 was homology modeled using 4-aminobutyrate aminotransferase from E. coli (PDB ID: 1SFF chain A) [51] as a template. 


\section{Additional files}

Additional file 1: Figure S1. Expression levels of the davA and davB genes in recombinant $C$. glutamicum $B E$ harboring p36davAB1, p36davAB2, and p36davAB3, all of which were examined by electrophoresis on a $12 \%(\mathrm{w} / \mathrm{v})$ sodium dodecylsultate-polyacrylamide gel (SDS-PAGE). $T$ and $\mathrm{S}$ stand for total fraction and soluble fraction, respectively

Additional file 2: Figure S2. Molecular docking with C. glutamicum GabT. Selected residues in the PLP-binding pocket from the SWISS MODEL-predicted molecular structure of C. glutamicum GabT (magenta) are shown. The lle261 residue (orange) near the predicted binding pocket for PLP from the original modeling simulation result protrudes into the binding pocket, thereby hindering subsequent docking simulations. This residue was corrected based on a known crystal structure of a different enzyme (yellow; PDB ID: 3LV2) with the correct lle orientation at the same position.

Additional file 3: Figure S3. Molecular docking of external aldimine with C. glutamicum GabT. (A) Molecular docking of external aldimine (grey; PLP and $\gamma$-aminobutyrate) to homology-modeled GabT from C. glutamicum (magenta). A known crystal structure of GabT from Arthrobacter aurescens (green, PDB ID: 4ATQ) (Bruce et al. [49]) is superimposed for comparison. (B) Molecular docking of external aldimine (blue; PLP and AVA) to homology-modeled GabT from C. glutamicum (magenta). Homology-modeled DavT from P. putida (salmon) and homology-modeled GabT from S. griseus (cyan) are superimposed for comparison.

Additional file 4: Figure S4. Simulation of molecular docking of 5AVA to homology-modeled DavT from P. putida KT2440. DavT was homologymodeled based on a known structure (PDB ID: 1SFF).

Additional file 5: Table S1. Strains and plasmids used in this study.

Additional file 6: Table S2. Primers used in this study.

Additional file 7: Table S3. Sequence of codon optimized davA and davB genes from P. putida.

\section{Abbreviations}

5AVA: 5-aminovalerate; SOD: superoxide dismutase; IPTG: isopropyl- $\beta$-D-thiogalactopyranoside.

\section{Authors' contributions}

SYL and SJP conceived the project. JHS, JSC, and JWC performed the experiments. SJP, JHS, SHP, YHO, MHL, KJJ, JCJ, and JY analyzed the data. JHS, SJP, and SYL wrote the manuscript. All authors read and approved the final manuscript.

\section{Author details}

1 Department of Chemical and Biomolecular Engineering (BK21 Plus program), Institute for the BioCentury, Center for Systems and Synthetic Biotechnology, KAIST, 291 Daehak-ro, Yuseong-gu, Daejeon 34141, Republic of Korea. ${ }^{2}$ Metabolic Engineering National Research Laboratory and BioProcess Engineering Research Center, KAIST, 291 Daehak-ro, Yuseong-gu, Daejeon 34141, Republic of Korea. ${ }^{3}$ Bioinformatics Research Center, KAIST, 291 Daehak-ro, Yuseong-gu, Daejeon 34141, Republic of Korea. ${ }^{4}$ Division of Convergence Chemistry, Center for Bio-based Chemistry, Korea Research Institute of Chemical Technology, P.O. Box 107, 141 Gajeong-ro, Yuseong-gu, Daejeon 34602, Republic of Korea. ${ }^{5}$ Department of Environmental Engineering and Energy, Myongji University, 116 Myongji-ro, Cheoin-gu, Yongin, Gyeonggido 17058, Republic of Korea.

\section{Acknowledgements}

This work was supported the Technology Development Program to solve climate changes (Systems Metabolic Engineering for Biorefineries) (NRF-2012M1A2A2026556 and NRF-2012M1A2A2026557) from the Ministry of Science, ICT and Future Planning (MSIP) through the National Research Foundation (NRF) of Korea and NRF grant funded by the MSIP (NRF-2016R1A2B4008707).

\section{Competing interests}

The authors declare that they have no competing interests.
Availability of data and materials

Please contact corresponding author for data requests.

\section{Consent for publication}

Our manuscript does not contain any individual person's data in any form.

\section{Ethics approval and consent to participate}

Our manuscript does not report data collected from humans or animals.

Received: 19 August 2016 Accepted: 22 September 2016

Published online: 07 October 2016

\section{References}

1. Oh YH, Eom IY, Joo JC, Yu JH, Song BK, Lee SH, et al. Recent advances in development of biomass pretreatment technologies used in biorefinery for the production of bio-based fuels, chemicals and polymers. Korean J Chem Eng. 2015;32:1945-59.

2. Choi YJ, Lee SY. Microbial production of short-chain alkanes. Nature 2013;502:571-4.

3. Atabani AE, Silitonga AS, Badruddin IA, Mahlia TMI, Masjuki HH, Mekhilef S. A comprehensive review on biodiesel as an alternative energy resource and its characteristics. Renew Sust Energ Rev. 2012;16:2070-93.

4. Jang YS, Lee SY. Recent advances in biobutanol production. Industrial Biotechnol. 2015;11:316-21.

5. Becker J, Klopprogge C, Zelder O, Heinzle E, Wittmann C. Amplified expression of fructose 1,6-bisphosphatase in Corynebacterium glutamicum increases in vivo flux through the pentose phosphate pathway and lysine production on different carbon sources. Appl Environ Microbiol. 2005:71:8587-96.

6. Becker J, Wittmann C. Systems and synthetic metabolic engineering for amino acid production - the heartbeat of industrial strain development. Curr Opin Biotechnol. 2012;23:718-26.

7. Lee KH, Park JH, Kim TY, Kim HU, Lee SY. Systems metabolic engineering of Escherichia coli for L-threonine production. Mol Syst Biol. 2007;3:149.

8. Park JH, Lee KH, Kim TY, Lee SY. Metabolic engineering of Escherichia coli for the production of L-valine based on transcriptome analysis and in silico gene knockout simulation. Proc Natl Acad Sci USA. 2007;104:7797-802.

9. Park JH, Oh JE, Lee KH, Kim JY, Lee SY. Rational design of Escherichia coli for L-isoleucine production. ACS Synth Biol. 2012;1:532-40.

10. Chen GQ, Hajnal I, Wu H, Lv L, Ye J. Engineering biosynthesis mechanisms for diversifying polyhydroxyalkanoates. Trends Biotechnol. 2015;33:565-74.

11. Choi SY, Park SJ, Kim WJ, Yang JE, Lee H, Shin J, et al. One-step fermentative production of poly(lactate-co-glycolate) from carbohydrates in Escherichia coli. Nat Biotechnol. 2016:34:435-40.

12. Kim HS, Oh YH, Jang YA, Kang KH, David Y, Yu JH, et al. Recombinant Ralstonia eutropha engineered to utilize xylose and its use for the production of poly(3-hydroxybutyrate) from sunflower stalk hydrolysate solution. Microb Cell Fact. 2016;15:95.

13. Qian ZG, Xia XX, Lee SY. Metabolic engineering of Escherichia coli for the production of putrescine: a four carbon diamine. Biotechnol Bioeng. 2009;104:651-62.

14. Tokuyama K, Ohno S, Yoshikawa K, Hirasawa T, Tanaka S, Furusawa C, et al. Increased 3-hydroxypropionic acid production from glycerol, by modification of central metabolism in Escherichia coli. Microb Cell Fact. 2014:13:1-11

15. Yim H, Haselbeck R, Niu W, Pujol-Baxley C, Burgard A, Boldt J, et al. Metabolic engineering of Escherichia coli for direct production of 1,4-butanediol. Nat Chem Biol. 2011;7:445-52

16. Lee JW, Na D, Park JM, Lee J, Choi S, Lee SY. Systems metabolic engineering of microorganisms for natural and non-natural chemicals. Nat Chem Biol. 2012;8:536-46.

17. Lee SY, Kim HU. Systems strategies for developing industrial microbial strains. Nat Biotech. 2015;33:1061-72.

18. Adkins J, Jordan J, Nielsen DR. Engineering Escherichia coli for renewable production of the 5-carbon polyamide building-blocks 5-aminovalerate and glutarate. Biotechnol Bioeng. 2013;1 10:1726-34. 
19. Pukin AV, Boeriu CG, Scott EL, Sanders JPM, Franssen MCR. An efficient enzymatic synthesis of 5-aminovaleric acid. J Mol Catal B Enzym. 2010;65:58-62.

20. Park SJ, Oh YH, Noh W, Kim HY, Shin JH, Lee EG, et al. High-level conversion of L-lysine into 5-aminovalerate that can be used for nylon 6,5 synthesis. Biotechnol J. 2014;9:1322-8.

21. Park SJ, Kim EY, Noh W, Park HM, Oh YH, Lee SH, et al. Metabolic engineering of Escherichia coli for the production of 5-aminovalerate and glutarate as C5 platform chemicals. Metab Eng. 2013;16:42-7.

22. Song CW, Lee J, Ko YS, Lee SY. Metabolic engineering of Escherichia coli for the production of 3-aminopropionic acid. Metab Eng. 2015;30:121-9.

23. Dung Pham V, Somasundaram S, Lee SH, Park SJ, Hong SH. Efficient production of gamma-aminobutyric acid using Escherichia coli by colocalization of glutamate synthase, glutamate decarboxylase, and GABA transporter. J Ind Microbiol Biotechnol. 2016;43:79-86.

24. Becker J, Wittmann C. Bio-based production of chemicals, materials and fuels -Corynebacterium glutamicum as versatile cell factory. Curr Opin Biotechnol. 2012:23:631-40.

25. Becker J, Wittmann C. Advanced biotechnology: metabolically engineered cells for the bio-based production of chemicals and fuels, materials, and health-care products. Angew Chem Int Ed Engl. 2015;54:3328-50.

26. Buschke N, Becker J, Schafer R, Kiefer P, Biedendieck R, Wittmann C. Systems metabolic engineering of xylose-utilizing Corynebacterium glutamicum for production of 1,5-diaminopentane. Biotechnol J. 2013;8:557-70.

27. Kind S, Jeong WK, Schroder H, Wittmann C. Systems-wide metabolic pathway engineering in Corynebacterium glutamicum for bio-based production of diaminopentane. Metab Eng. 2010;12:341-51.

28. Kind S, Kreye S, Wittmann C. Metabolic engineering of cellular transport for overproduction of the platform chemical 1,5-diaminopentane in Corynebacterium glutamicum. Metab Eng. 2011;13:617-27.

29. Kind S, Neubauer S, Becker J, Yamamoto M, Volkert M, Abendroth G, et al. From zero to hero - production of bio-based nylon from renewable resources using engineered Corynebacterium glutamicum. Metab Eng. 2014;25:113-23.

30. Oh YH, Choi JW, Kim EY, Song BK, Jeong KJ, Park K, et al. Construction of synthetic promoter-based expression cassettes for the production of cadaverine in recombinant Corynebacterium glutamicum. Appl Biochem Biotechnol. 2015;176:2065-75.

31. Eikmanns BJ, Kleinertz E, Liebl W, Sahm H. A family of Corynebacterium glutamicum/Escherichia coli shuttle vectors for cloning, controlled gene expression, and promoter probing. Gene. 1991;102:93-8.

32. Santamaria R, Gil J, Mesas J, Martin J. Characterization of an endogenous plasmid and development of cloning vectors and a transformation system in Brevibacterium lactofermentum. J Gen Microbiol. 1984;130:2237-46.

33. Venkova-Canova T, Patek M, Nesvera J. Characterization of the cryptic plasmid pCC1 from Corynebacterium callunae and its use for vector construction. Plasmid. 2004:51:54-60.

34. Becker J, Zelder O, Hafner S, Schroder H, Wittmann C. From zero to hero-design-based systems metabolic engineering of Corynebacterium glutamicum for L-lysine production. Metab Eng. 2011;13:159-68.

35. Ravasi P, Peiru S, Gramajo H, Menzella HG. Design and testing of a synthetic biology framework for genetic engineering of Corynebacterium glutamicum. Microb Cell Fact. 2012;11:1-11.

36. Yim SS, An SJ, Kang M, Lee J, Jeong KJ. Isolation of fully synthetic promoters for high-level gene expression in Corynebacterium glutamicum. Biotechnol Bioeng. 2013;110:2959-69.
37. Choi JW, Yim SS, Lee SH, Kang TJ, Park SJ, Jeong KJ. Enhanced production of gamma-aminobutyrate (GABA) in recombinant Corynebacterium glutamicum by expressing glutamate decarboxylase active in expanded pH range. Microb Cell Fact. 2015;14:21.

38. Park JU, Jo JH, Kim YJ, Chung SS, Lee JH, Lee HH. Construction of heatinducible expression vector of Corynebacterium glutamicum and $C$. ammoniagenes: fusion of lambda operator with promoters isolated from C. ammoniagenes. J Microbiol Biotechnol. 2008;18:639-47.

39. Cebe R, Geiser M. Rapid and easy thermodynamic optimization of the 5'-end of mRNA dramatically increases the level of wild type protein expression in Escherichia coli. Protein Expr Purif. 2006;45:374-80.

40. Jang SH, Lee CH, Kim YS, Jeong KJ. High-level production of a kringle domain variant by high-cell-density cultivation of Escherichia coli. Appl Microbiol Biotechnol. 2011;92:327-36.

41. Kim SY, Lee J, Lee SY. Metabolic engineering of Corynebacterium glutamicum for the production of L-Ornithine. Biotechnol Bioeng. 2015;112:416-21.

42. Yonaha K, Suzuki K, Toyama S. 4-Aminobutyrate:2-oxoglutarate aminotransferase of Streptomyces griseus: purification and properties. Eur J Biochem. 1985;146:101-6.

43. Sambrook J, Russell DW. Molecular cloning: a laboratory manual. 3rd ed. Cold spring harbor: Cold spring harbor laboratory press; 2001.

44. Kind S, Becker J, Wittmann C. Increased lysine production by flux coupling of the tricarboxylic acid cycle and the lysine biosynthetic pathway - metabolic engineering of the availability of succinyl-CoA in Corynebacterium glutamicum. Metab Eng. 2013;15:184-95.

45. Schafer A, Tauch A, Jager W, Kalinowski J, Thierbach G, Puhler A. Small mobilizable multi-purpose cloning vectors derived from the Escherichia coli plasmids PK18 and pK19: selection of defined deletions in the chromosome of Corynebacterium glutamicum. Gene. 1994;145:69-73.

46. Park SH, Kim HU, Kim TY, Park JS, Kim SS, Lee SY. Metabolic engineering of Corynebacterium glutamicum for L-arginine production. Nat Commun. 2014:5:4618.

47. Koffas MAG, Jung GY, Aon JC, Stephanopoulos G. Effect of pyruvate carboxylase overexpression on the physiology of Corynebacterium glutamicum. Appl Environ Microb. 2002;68:5422-8.

48. Morris GM, Huey R, Lindstrom W, Sanner MF, Belew RK, Goodsell DS, et al. AutoDock4 and AutoDockTools4: automated docking with selective receptor flexibility. J Comput Chem. 2009;30:2785-91.

49. Bruce H, Nguyen Tuan A, Mangas Sanchez J, Leese C, Hopwood J, Hyde $R$, et al. Structures of a gamma-aminobutyrate (GABA) transaminase from the s-triazine-degrading organism Arthrobacter aurescens TC1 in complex with PLP and with its external aldimine PLP-GABA adduct. Acta Crystallogr, Sect F: Struct Biol Cryst Commun. 2012;68:1175-80.

50. Arnold K, Bordoli L, Kopp J, Schwede T. The SWISS-MODEL workspace: a web-based environment for protein structure homology modelling. Bioinformatics. 2006;22:195-201.

51. Liu W, Peterson PE, Carter RJ, Zhou X, Langston JA, Fisher AJ, et al. Crystal structures of unbound and aminooxyacetate-bound Escherichia coli gamma-aminobutyrate aminotransferase. Biochemistry. 2004:43:10896-905.

\section{Submit your next manuscript to BioMed Central and we will help you at every step:}

- We accept pre-submission inquiries

- Our selector tool helps you to find the most relevant journal

- We provide round the clock customer support

- Convenient online submission

- Thorough peer review

- Inclusion in PubMed and all major indexing services

- Maximum visibility for your research

Submit your manuscript at www.biomedcentral.com/submit 